\title{
Google Classroom as E-learning Mode at SMP YPM 7 Sidoarjo
}

\author{
Rangga Kusuma Admaja \\ STKIP PGRI Sidoarjo, email: ranggakusumaadmaja.rka@gmail.com
}

\author{
J. Priyanto Widodo \\ STKIP PGRI Sidoarjo, email: prowidodo18@gmail.com \\ Fabiola D. Kurnia \\ STKIP PGRI Sidoarjo, email: fabkurnia@gmail.com
}

\begin{abstract}
Technology has grown speedily so that people can access the internet and also can communicate with others easily. By means the development of technology, many people use it not only as a communication tool but also for the implementation in the educational world in regard students learn to use computers and all things about technology. Furthermore, students and teacher can also do teaching and learning activities online, Google Classroom, as one of the online learning platforms that applied at SMP YPM 7 Sidoarjo. Based on the background of the study, the purpose of the study focuses to discribe How is the implementation of e-learning by using google classroom at SMP YPM 7 Sidoarjo and what the students' perception. In order to answer the two formulated research questions, there are two types of instruments in this research. Those obtained from document google classroom and questionnaire. This is a qualitative research design the writer describe the data briefly. This research conducted under the assumptions there are various perceptions towards the implementation of google classroom as E-learning at SMP YPM 7 Sidoarjo. Whereas, the result of the questionnaire explain about the Perception of the student, the instrument showed that the student's majority had a positive Perspection. The conclusion in this research is there is neccesity to elaborate some suggestions regarding google classroom as e-learning the The teacher should be more explore application of google classroom it self.
\end{abstract}

Keywords: Google Classroom, E-learning Mode, Student Perception

\section{INTRODUCTION}

Technology has grown speedily so that people can access the internet and also can communicate with others easily. One of the technologies that is developed very quickly and used in various activities is the internet. More than anything else, technology creates the world for instance wealth, economy, and very way of being (Arthur, 2009, p. 10). By means of the development of technology, many people use it not only as a communication tool but also for the implementation in the educational world in regard students learn to use computers and all 
things about technology. Furthermore, students and teacher can also do teaching and learning activities online. Students can also learn through the internet where at this time learning materials are widely available on the internet as well as for an internet teacher is needed to look for teaching materials in class. Teachers can also conduct the process of teaching and learning outside the classroom by using the application on the internet students can interact with teachers, receive learning materials like learning activities at school.

The spread of COVID-19 has led to the shutting of educational institutions all over the world. A closure enhanced the development of the online learning environments within those institutions so that learning might not be disrupted. "The coronavirus pandemic has tested as it is important to review the reasons for offering students online classes, which go beyond periods of confinement (CAE-Team, 2020)." Additionally, starting the development of the use of distance learning in several universities in Indonesia as the impact of the Covid-19 issue, applying e-learning as one of their tools in delivering teaching and learning has been done. Google Classroom, as one of the online learning platforms that applied at SMP YPM 7 Sidoarjo. Google Classroom also offers features that can encourage students to learn cooperatively. Thus, it is assumed that google classroom is an essential tool in determining the usefulness as well as its benefits and challenges from the lecturers and students' interpretations.

On the other side, online learning by implementing google classroom has many challenges. (Amadea \& Dahesihsari, 2015) argued "Some complications revealed in the use of online learning such as: limited access due to poor internet connection." Lack of connectivity becomes the main to the students and teacher while doing the online learning, it might impact students' motivation to learn using online learning. Furthermore, based on pre-observations at SMP YPM 7 Sidoarjo, some students of the $7^{\text {th }}$ grade said their most significant obstacle in using Google Classroom is the internet connection. With the disruption of internet connection, it affects the purpose of features in e-learning, it will make the features performance less maximum, for example video chatting, that necessitate a speed internet connection. Some of the students also complained about the steep downloading material. Students cannot exactly download the material in one click. Some of them also deplore of the use of e-learning limited only for giving an assignment and collecting the assignment. Some of them claim that elearning is less practical. It is implied that the implementation of platform google classroom has many perceptions among the students. Based on what is presented in the background, the researcher is interested in more challenges research on the implementation of platform Google Classroom at SMP YPM 7 Sidoarjo regarding students' perception. Therefore, the researcher entitled "Google Classroom as E-learning Mode at SMP YPM 7 Sidoarjo". Based on the 
background of the study above, the problem is stated: (1) How is the implementation of elearning by using platform google classroom at SMP YPM 7 Sidoarjo? and (2) What are the students' perceptions of the implementation of e-learning by using platform google classroom at SMP YPM 7 Sidoarjo? The assumptions of this research are: there are various perceptions towards the implementation of google classroom as E-learning at SMP YPM 7 Sidoarjo.

\section{REVIEW OF LITERATURE}

\section{Definition of Perception}

Individuals are created differently and have different insights between individuals with each other by liking one object and some who do not like the object; it really depends on how the individual responds to the object with its perception. Aristotle stated about perception is the associated with a change in a sense-organ and this is caused by the object of perception (Knuutilla \& Karkkainen, 2008, p.1). It is implied regarding to Aristotle's theory of perception that changes in the sense-organ and this is caused by the object of perception which means individual has feelings of likes or dislikes for the intended object.

\section{E-learning}

There are several methods used in e-learning, the method be used in some educational fields that be adjusted with its function. E-learning functions as a supplement, as a complement, and as a substitute (Hendrastomo, 2008). It is as a supplement if learners are given the freedom to choose whether to use e-learning or not. There is no obligation for the students to access the material through e-learning. It is as a complement if e-learning materials are programmed as a learning program to complete the learning materials received in the classroom. As a complement means e-learning material is programmed to be enrichment and remedial materials for the learner in following the conventional learning activities. As a substitute, is intended for students who enable to not follow the conventional class.

\section{Guideline of E-learning activities}

According Weerasinghe, Ramberg, \& Hewagamage (2009) Guideline of E-learning actoivities, Give learners the control of their interactions with media, Design interactive learning content, Check whether a simple script can handle the interactivity. If not add/design interactivity using Flash animations, Check the database for available media elements before designing a new one, Motivate learners to provide feedback to other learners' work, Allocate enough time to carry out the discussion, Conduct instructor-led discussions or chats, Train the staff to provide facilitation (Consider the quality and the quantity of teacher interactions), Provide timely and meaningful feedback, Inform purpose of the discussion and the deadlines. 


\section{Google Classroom}

Google Classroom is developed by Google for academic purposes that support a blended learning platform. This application is so simple to use, does not take too many spaces on smartphone's memory and help teacher and student keep on the lesson's track. The users can create a virtual class where can be functions as in conventional class but save more time, money, and space. Google Classroom is a tool which facilitates students and teacher collaboration. Then, teacher can create and distribute assignments for students in an online classroom for free (Beal, 2017). It makes teachers simply build groups to share assignments and announcements. Google Classroom can be a tool that makes learners become active participants.

Nagele (2017) argued teachers can create active lessons which are student-centered, collaborative, and unforgettable just through Google Classroom due to it provides easy-to-use learning features with students of all categories able to cooperate. Google Classroom is helpful to all of learner categories and including adult learners. Moreover, google classroom also has some benefits such as paperless, can be accessed anywhere and everywhere as long as there is internet connection and from any devices, to communicate between teachers and students, to give feedback to students, and personalized learning. It has a learning feature that makes teachers create and handle assignments actively and also provide feedback to students.

\section{RESEARCH METHOD}

\section{Research Design}

The researcher was to apply descriptive qualitative method for completing this research due to the aims to examine and describe In this research, the researcher essentially describes the situation in which how students perceive the implementation of google classroom in the teaching and learning activities at SMP YPM 7 Sidoarjo. In order to answer the two formulated research questions, there are two types of instruments in this research. Those obtained from document google classroom and questionnaire.

\section{RESULTS AND DISCUSSION}

The researcher described all the activities that happened in the class, The description was about the how is the implementation by using google classroom. The teacher gives online material and assignments to students with a material expression of apologizing, the teacher 
provides instructions by showing the material in the book and reading examples of dialogue in the given LKPD image files, the teacher does not give a time limit so that students are not overwhelmed but keep emphasizing to start learning and working on today. After a few minutes, ten students have finished working on assignments and sent them to google classroom, while some students confirmed that they would send assignments directly to school due to several factors such as internet access, limited internet quota, cell phone problems, sick leave, and other dispensations.

The teacher provides online material through google classroom about chapter 2 , telling family members, through short messages, the teacher says greetings and recites prayers to start learning and tells the objectives of today's online learning. At this time, the teacher gave the assignment to work on English worksheets. Assignments can be done on lined folio paper, and do not forget to include name, class, and absent number. Worksheets are photographed and sent via google classroom, and this time for the first time, students are given the opportunity to come together to school to get a learning clinic while adhering to health protocols. Students are expected to bring all the tasks that have been done previously in the form of hard files or student worksheets beforehand to be checked and assisted in understanding material that they still did not understand when learning from in Google Classroom. As for the different learning this time has been confirmed by the school by promoting the right of students to better understand learning and health protocols. The researcher presented the finding from the students questionnaire. This questionnaire contented 14 questions. The instrument distributed to 36 student using Google Form, there were 36 students join to google form and give their perceptions. the criteria of the student's answer, the researcher analyzed the result of the questionnaire by using percentage from google classroom. The finding are presented as follows 
Table 4.1.2a (The result of the questionnaire)

\begin{tabular}{|c|c|c|c|c|c|}
\hline No & Items & $\begin{array}{l}\mathrm{SS} \\
(\%)\end{array}$ & $\begin{array}{c}\mathrm{S} \\
(\%)\end{array}$ & $\begin{array}{l}\mathrm{TS} \\
(\%)\end{array}$ & $\begin{array}{l}\text { STS } \\
(\%)\end{array}$ \\
\hline 1 & $\begin{array}{l}\text { Google classroom gives me the } \\
\text { opportunity to interact with } \\
\text { teachers through virtual classes }\end{array}$ & $19,4 \%$ & $75 \%$ & $2,8 \%$ & $2,8 \%$ \\
\hline 2 & $\begin{array}{l}\text { Google classroom makes the } \\
\text { learning process easier }\end{array}$ & $22,2 \%$ & $72,2 \%$ & $5,6 \%$ & $0 \%$ \\
\hline 3 & $\begin{array}{l}\text { Google classroom supports the } \\
\text { virtual learning process }\end{array}$ & $27,8 \%$ & $66,7 \%$ & $5,6 \%$ & $0 \%$ \\
\hline 4 & $\begin{array}{l}\text { Google classroom is an effective } \\
\text { application in collecting } \\
\text { assignments }\end{array}$ & $30,6 \%$ & $63,9 \%$ & $5,6 \%$ & $0 \%$ \\
\hline 5 & $\begin{array}{l}\text { Google classroom helps me to } \\
\text { submit assignments on time }\end{array}$ & $25 \%$ & $72,2 \%$ & $2,8 \%$ & $0 \%$ \\
\hline 6 & $\begin{array}{l}\text { Google classroom gives me the } \\
\text { opportunity to have a virtual } \\
\text { class discussion }\end{array}$ & $25 \%$ & $58,3 \%$ & $16,7 \%$ & $0 \%$ \\
\hline 7 & $\begin{array}{l}\text { The assessment of google } \\
\text { classrooms help me to } \\
\text { monitoring my study and } \\
\text { understanding the topic which is } \\
\text { being discussed this time }\end{array}$ & $22,2 \%$ & $66,7 \%$ & $11.1 \%$ & $0 \%$ \\
\hline 8 & $\begin{array}{l}\text { Google classrooms easy to } \\
\text { accessed }\end{array}$ & $33,3 \%$ & $58,3 \%$ & $8,3 \%$ & $0 \%$ \\
\hline 9 & $\begin{array}{l}\text { Google classrooms is the best } \\
\text { media to interact with the } \\
\text { teacher and classmate }\end{array}$ & $33,3 \%$ & $50 \%$ & $13,9 \%$ & $2,8 \%$ \\
\hline 10 & $\begin{array}{l}\text { The feedback provided by the } \\
\text { teacher throught Google } \\
\text { Classroom is useful }\end{array}$ & $25 \%$ & $69,4 \%$ & $5,6 \%$ & $0 \%$ \\
\hline 11 & $\begin{array}{l}\text { I feel comfortable when learning } \\
\text { using Google Classroom }\end{array}$ & $25 \%$ & $63,9 \%$ & $8,3 \%$ & $2,8 \%$ \\
\hline 12 & $\begin{array}{l}\text { I would recommend this method } \\
\text { of splitting to apply to other } \\
\text { suitable subjects }\end{array}$ & $22,2 \%$ & $63,9 \%$ & $13,9 \%$ & $0 \%$ \\
\hline 13 & $\begin{array}{l}\text { I like using google classroom } \\
\text { because it can motivate my } \\
\text { learning }\end{array}$ & $19,4 \%$ & $69,4 \%$ & $8,3 \%$ & $0 \%$ \\
\hline
\end{tabular}




\begin{tabular}{|c|l|c|c|c|c|}
\hline 14 & $\begin{array}{l}\text { I have no problem using Google } \\
\text { Classroom }\end{array}$ & $27,8 \%$ & $52,2 \%$ & $19,4 \%$ & $0 \%$ \\
\hline
\end{tabular}

Based on the results of the document google classroom, and result student's questionnaire in platform Google Classroom, there were several points to be discussed further able to describe below :

\section{Implementation of Google Classroom}

Based on the findings teaching learning process in at Google classroom always had the similarities each meeting differences in material topic, the teacher taught the student use google classroom gave them instructions how to learn, the teacher always showed the general content of the book and explain about the purpose they study. The teacher use short message and link video and material to make the students understands the teacher gave assigment in the last instruction message. The application of google classroom provides new, more effective teaching variations and makes it easier for students in the learning process, the features in the google classroom application are various, providing solutions to teachers in the learning process in the pandemic era. Which does not allow face-to-face learning. Based on Nagale (2017) argued teachers can create active lessons that are student-centered, collaborative, and unforgettable just through Google Classroom due to it provides easy-to-use learning features with students of all categories able to cooperate.

Supporting by Agarwal \& Pandey (2012), e-learning focuses on the use of technology in learning and education that refers to the use of information and communication technology in learning process which consists of electronic devices. the teacher always use platform google classroom pays attention to students, what they do not understand and provides stimulation in the form of an image or video link material that makes them interested in observing the material given.

Afterwards, it was found that concept of guideline E-learning activities According Soliman (2014), E-learning activities could be used to enhance students' language proficiency and independent learning as will be explained at the end of each activity : The activities include assignment, chat, choice, Database, External Tool, Forum, Glossary, Hotpot, lesson, Quiz, SCORM Package, Survey, Wiki, and Workshop. the researcher was assumed about platform Google classroom which was used in SMP YPM 7 Sidoarjo have similarities with the statement above. Base on Weerasinghe, Ramberg, \& Hewagamage (2009) there are a subset of design 
guidelines to design learning activities and the research make a coparison witH activities at SMP YPM 7 Sidoarjo, learning activities at SMP YPM 7 Sidoarjo use asynchrounous learning, where learning is virtual but not live directly, Supporting (Wahono 2008) Asynchronous enable the students to complete the web-based training at their own place, without live instruction from the teacher. the application of platform google classroom as E-learning at SMP YPM 7 Sidoarjo is not much different from the e-learning guideline itself, even if compared, it turns out that there are more similarities, even though the knowledge or skills in running the Google Classroom platform itself must be given guidance, the more proficient in use Of course, it will provide more variety in the teaching process through virtual classes.

\section{Students' perceptions}

The point of the questions related Aristotle stated about perception is the associated with a change in a sense-organ and this is caused by the object of perception (Knuutilla \& Karkkainen, 2008, p.1). with to Aristotle's theory of perception that changes in the sense-organ and this is caused by the object of perception which means individual has feelings of likes or dislikes for the intended object base on the questionnaire students feel that they like Google even though few think they don't like the Google classroom application. The perception is well-known as the awareness familiarity regarding what people sense (Demuth, 2003, p. 25). Based on the findings using students' questionnaire. The researcher found out that the student's had a positive perspective. Majority of the students agree that google classroom gave the students opportunity to interact with teachers through virtual classes, Google classroom makes the learning process easier, Google classroom supports the virtual learning process, Google classroom is an effective application in collecting assignments, Google classroom helps to submit assignments on time, Google classroom gives the opportunity to have a virtual class discussion, The assessment of google classrooms help to monitoring and understanding the topic which is being discussed this time, Google classrooms easy to accessed, Google classrooms is the best media to interact with the teacher and classmate, The feedback provided by the teacher throught Google Classroom is useful, The student's comfortable when learning using Google Classroom, and would recommend this method of splitting to apply to other suitable subjects, They felt helpfull by google classroom, but sometimes the students still often nervous and had the difficulty in learning virtual clases, According Kreitner and Kinicki (in Pratiwi 2013: 25) claimed that perception as a mental and cognitive process that makes people to interpret and understand the environments. In addition, it is argued perception as the way of 
stimulations which are selected, so it can be a meaningfully interpreted. Moreover, perception is described as the response to stimulus or to surroundings.

\section{CONCLUSIONS}

Based on the findings and the result of discussion, it is that :

This study was conducted to find out the implementation. Based on the result and data analysis, the researched conclude that there are various perceptions towards the implementation of platform google classroom as online tool at SMP YPM 7 Sidoarjo. Based on the result and data analysis by the questionnaire, the students perceptions was positive in platform Google classroom. Most of the students answered positively, they were interested in the google classroom. Based on the findings and the result of discussion, there is neccesity to elaborate some suggestions regarding to the teaching method used by the Lecturer in nursing academy program. Afterward, the researcher conveys several suggestions based on saveral factors as follows:

The teacher should be more explore application of google classroom, give some motivation to the student to study more and active to be a patner for the students in teaching learning virtual clases. The students should have efforts to learn English by reading their material link book, image, and video share by the teacher. The students should be active participants in teaching learning process by asking some question to make clear what they do not understand. The future researcher may cope and colaborate the implemantation of google classroom as E-learning more deeply to find a better use and meaningful way in implementing google classroom as E learning. The future researcher had better conduct the researcher with this teaching by providing pre-test and post-test to know the improvement their skill.

\section{REFERENCES}

Amadea, M., \& Dahesihsari, R. (2015). Hambatan dalam Pengadopsian E-Learning pada Pengajar Perguruan Tinggi di Jabodetabek. Jurnal Kependidikan.

Arthur, W. B. (2009). The Nature of Technology: What It Is and How it Evolves. New York: Free Press. 
Ary, e. a. (2010). Introduction to Research in Education (8th Ed.). Wadsworth, USA: Cengage Learning, USA.

CAE-Team. (2020). COVID-19 Virus: Changes in Education. Retrieved August 15, 2020, from https://www.cae.net/covid-19-virus-changes-in-education/

Chen, Y., \& Hoshower, L. B. (2003). Student Evaluation of Teaching Effectiveness: An Assessment of Student Perception and Motivation . Carfax Publishing. Vol. 28 No.1.

Cox, J. (2009). Teachhub. Retrieved August 10, 2020, from http://www.teachhub.com/benefits-technology-classroom

Cresswell, J. W. (2012). Educational Research: Planning, Conducting, and Evaluating Quantitative and Qualitative Research . (4th Ed.). Newy York: Pearson Education, Inc.

Curtis, S. (2013). How technology is changing childhood. Retrieved August 10, 2020, from https://www.telegraph.co.uk/technology/news/10529

Demuth, A. (2003). Perception Theories . Sloakov: Edicia Kognitivne Studia.

Diaz, S. B., Diniz, J. A., \& Hadjileontiadis, L. J. (2014). Towards an Inteligent Learning Management System Under Blended Learning. Switzerland: Springer.

Fraenkel, J. R., \& Wallen, N. E. (2009). How to Design and Evaluate Research in Education. New York : McGraw-Hill.

Hussaini, I., Ibrahim, S., Wali, B., Libata, I., \& Musa, U. (2020). Effectiveness of Google Classroom as a Digital Tool in Teaching and Learning: Students' Perceptions. International Journal of Research and Innovation in Social Science (IJRISS), Volume IV, Issue IV, 51-54.

Islam, M. S. (2019). Bangladeshi University Students' Perception on Using Google Classroom for Teaching Ennglish . International Journal of Psycho-Educational Sciences, Vol.8, No.2, 57-65.

Knuutilla, S., \& Karkkainen, P. (2008). Theories of Perception in Medieval and Early Modern Philosophy. Finland: Springer.

Montague, M. (1997). Student Perception, Mathematical Problem Solving, and Learning Disabilities . Pennsylvania State Univ. Vol.8 No.1. 
Pratiwi, W. D. (2013). Students' Perception towards Teacher's Written Feedback among 11th Grade Students at SMA N 1 Wedi Klaten. Yogyakarta: State University of Yogyakarta.

Smaldino, S. E., Lowther, D. L., \& Russel, J. (2012). Instructional Technology and Media or Learning . Boston: Pearson Education, Inc.

Weerasinghe, T. A., Ramberg, R., \& Hewagamage,, K. P. (2009). Designing online learning environments for distance learning. International Journal of Instructional Technology and Distance Learning. vol.6, no. 3. 